\title{
Student'sSocial Skills Through the Application of Cooperative Learning Rotating Trio Exchange at Class X MIPA SMA
}

\author{
Ressy Rilianika $^{* 1)}$, Nur Islami ${ }^{2}$, Zulirfan $^{3)}$, Yati Gusneli ${ }^{4)}$ \\ ${ }^{12,3)}$ Physics Education, University of Riau \\ ${ }^{4)}$ SMA Negeri 5 Pekanbaru \\ email: ${ }^{* 1)}$ ressy.ajha@gmail.com \\ nurislami@lecturer.unri.ac.id \\ zulirfan@lecturer.unri.ac.id \\ yatigusnelihairul@yahoo.co.id
}

\begin{abstract}
The purpose of this research was to describe the social skills of students in class X MIPA SMA Negeri 5 Pekanbaru, through the application of the rotating trio exchange (RTE) type of cooperative learning model on momentum and impulse material. This type of pre-experimental research with intact-group comparison design. The research subjects were students of class X MIPA 4 and class X MIPA 2, each of which totaled 36 students. The data were obtained from direct observation related to aspects of students' social skills by filling out the observation sheet for five indicators, namely: active listening, taking turns in sharing tasks, asking questions, cooperation, and tolerance. The results showed an increase in students' social skills through the application of the RTE cooperative learning model. The increase occurred in each indicator of students' social skills, where the indicators of active listening were $85.33 \%$ high category, taking turns in sharing tasks $86.33 \%$ high category, asking questions $66.67 \%$ medium category, cooperation $84.67 \%$ high category, and $82.00 \%$ tolerance high category. These results indicate that almost all of the observed indicators of students' social skills are in the high category, except the indicators asking questions which are in the medium category. Thus the application of the RTE cooperative learning model, in general, can improve students' social skills well in class X MIPA4 SMA 5 Pekanbaru.
\end{abstract}

Keywords: students' social skills, RTE cooperative learning, momentum and impulse. 


\title{
Keterampilan Sosial Siswa Melalui Penerapan Model Pembelajaran Kooperatif Tipe Rotating Trio Exchange di Kelas X MIPA SMA
}

\author{
Ressy Rilianika $^{* 1)}$, Nur Islami ${ }^{2)}$, Zulirfan $^{3)}$, Yati Gusneli ${ }^{4)}$ \\ ${ }^{12,3)}$ Physics Education, University of Riau \\ ${ }^{4)}$ SMA Negeri 5 Pekanbaru
}

\begin{abstract}
Abstrak
Tujuan penelitian ini adalah untuk mendeskripsikan kemampuan keterampilan sosial siswa di kelas X MIPA SMA Negeri 5 Pekanbaru melalui penerapan model pembelajaran kooperatif tipe Rotating Trio Exchange (RTE) pada materi momentum dan impuls. Jenis penelitian pre-eksperimen dengan rancangan Intact-Group Comparison. Subjek penelitian adalah siswa kelas X MIPA 4 dan kelas X MIPA 2 yang masing-masing berjumlah 36 siswa. Data didapatkan dari hasil observasi langsung terkait aspek keterampilan sosial siswa dengan cara mengisi lembar observasi untuk lima indikator yaitu: mendengar dengan aktif, mengambil giliran dalam berbagi tugas, mengajukan pertanyaan, kerjasama, dan toleransi. Hasil penelitian menunjukkan adanya peningkatan kemampuan keterampilan sosial siswa melalui penerapan model pembelajaran kooperatif RTE. Peningkatan terjadi pada setiap indikator keterampilan sosial siswa, dimana indikator mendengarkan dengan aktif $85,33 \%$ kategori tinggi, mengambil giliran dalam berbagi tugas $86,33 \%$ kategori tinggi, mengajukan pertanyaan $66,67 \%$ kategori sedang, kerjasama (gotong royong) $84,67 \%$ kategori tinggi, dan toleransi $82,00 \%$ kategori tinggi. Hasil ini menunjukkan bahwa hampir semua indikator keterampilan sosial siswa yang diobservasi berada pada kategori tinggi, kecuali indikator mengajukan pertanyaan yang berkategori sedang. Dengan demikian penerapan model pembelajaran kooperatif RTE secara umum dapat meningkatkan keterampilan sosial siswa dengan baik di kelas X MIPA4 $\mathrm{SMA}_{5}$ Pekanbaru.
\end{abstract}

Kata kunci: keterampilan sosia siswa, pembelajaran kooperatif RTE, momentum dan impuls.

\section{Pendahuluan}

Pembelajaran dalam kelas merupakan bagian yang sangat penting dari proses pendidikan. Peraturan Pemerintah RI nomor 19 tahun 2005 tentang standar nasional pendidikan yang diperjelas dengan Peraturan Menteri Pendidikan Nasional nomor 19 tahun 2007 tanggal 23 Mei 2007 tentang standar pengelolaan pendidikan dasar dan menengah menjelaskan bahwa mutu pembelajaran di sekolah dikembangkan dengan menggunakan model pembelajaran yang mengacu pada standar proses yang melibatkan peserta didik secara aktif, demokratis, mendidik, me-motivasi, mendorong kreativitas, dan dialogis. Diharapkan siswa mencapai pola pikir dan kebebasan berfikir, sehingga dapat melaksana-kan aktivitas intelektual daalam hal berfikir, berargumentasi, mempertanyakan, mengkaji, menemukan, dan memprediksi. Menurut Moejiono dalam Sagala (2007), salah satu faktor penting untuk mencapai tujuan pembelajaran adalah proses pembelajaran yang lebih menekankan pada keterlibatan siswa secara optimal.

Berdasarkan hasil studi pendahuluan di SMA Negeri 5 Pekanbaru khususnya kelas $\mathrm{X}$ MIPA, diperoleh beberapa informasi sebagai berikut: (1) Data nilai ulangan umum siswa pada tengah semester genap pada tahun ajaran 2018/2019, masih berada di bawah standar ratarata dengan kriteria ketuntasan minimal (KKM) yang ditetapkan sekolah yaitu sebesar 76, serta ketuntasan hasil belajar siswa masih rendah, yaitu hanya $62,96 \%$ dari 36 siswa yang tuntas, sedangkan $37,04 \%$ dari 36 siswa dinyatakan belum tuntas, (2) metode ceramah masih dominan digunakan, sehingga terfokus pada 
informasi guru dan interaksi antar siswa kurang optimal, pembelajaran kurang menerap-kan keterampilan sosial.

Menindak lanjuti permasalahan yang muncul dan dari hasil diskusi antara pengkaji dengan guru mitra, maka perlu dilakukan penelitian untuk meningkatkan keterampilan sosial siswa. Keterampilan sosial adalah kemampuan siswa dalam berkomunikasi efektif dengan siswa lain dalam menyelesaikan tugas kelompok yang diberikan, guna mencapai tujuan bersama (Susilowati, 2012). Keterampilan sosial ditekankan pada aspek mengajukan pertanyaan, menyampaikan pendapat menjawab pertanyaan, menghargai pendapat teman, membantu teman yang kesulitan memahami pelajaran, serta bekerjasama dengan baik.

Upaya yang dapat dilakukan meningkat-kan keterampilan sosial siswa, salah satunya yaitu dengan cara menerapkan suatu strategi pembelajaran yang mampu melatih keterampilan sosial siswa, yaitu dengan menggunakan model pembelajaran kooperatif (Fatimah et al., 2013). Hal ini mengacu pada penelitian yang telah dilakukan oleh Dinan (2014) bahwa "melatih dan mengembangkan keterampilan sosial siswa dalam proses pembelajaran dapat diintegrasikan melalui beberapa model pembelajaran, salah satunya adalah model cooperative learning. Proses pembelajaran kooperatif melibatkan proses pengambilan keputusan dan penyelesaian masalah, serta proses berbagi informasi yang relevan dan keahlian dengan orang lain (Huang et al., 2017; Nuraeni et al., 2016). Salah satu model pembelajaran kooperatif yang mampu melatih keterampilan sosial siswa yaitu tipe rotating trio exchange (RTE).

Model pembelajaran kooperatif tipe RTE yang dikembangkan oleh Silberman merupakan suatu cara mendalam bagi siswa untuk berdiskusi mengenai berbagai masalah dengan beberapa teman kelasnya. Silberman (2013) menyatakan bahwa model pembelajaran kooperatif tipe RTE termasuk model pembelajaran yang dapat meningkatkan partisipasi aktif siswa saat pembelajaran dengan mengoptimalkan kegiatan diskusi kecil antar anggota kelompok. Langkah-langkah dalam pembelajaran dengan menggunakan model cooperative learning tipe RTE menurut Isjoni,
(2014) yaitu: (a) Penjelasan terkait materi pembelajaran yang akan disampaikan dan materi yang akan didiskusikan. (b) Pembentukan kelompok secara heterogen yang terdiri dari 3 orang siswa dengan pemberian simbol 0,1 , dan 2. (c) Penjelasan prosedur Rotating Trio Exchange (RTE) dengan cara: (1) Setelah terbentuk kelompok, diberikan bahan diskusi untuk diselesaikan trio tersebut, (2) Kelompok menyajikan hasil diskusi di depan kelas, (3) Selanjutnya siswa yang mempunyai simbol 1 berpindah searah jarum jam dan simbol nomor 2 berlawanan jarum jam, sedangkan nomor 0 tetap di tempat, (4) Pemberikan pertanyaan baru atau bahan diskusi baru dari guru untuk didiskusikan oleh trio baru, (5) Penyajian hasil diskusi kelompok, (6) Setelah itu perputaran kelompok kembali dilakukan dengan simbol 1 dan 2 bertukar tempat, (7) Bahan diskusi menggunakan LKS dibagikan untuk dikerjakan bersama kelompok, (8) Penyajian hasil diskusi kelompok oleh siswa.

Adapun keunggulan dari model pembelajaran RTE antara lain: 1) Struktur yang jelas, sehingga memungkinkan siswa untuk berbagi dengan pasangan dalam kelompoknya dengan waktu yang teratur, 2) Siswa mempunyai banyak kesempatan untuk mengolah informasi, 3) Mengurangi kebosanan pada saat proses pembelajaran, karena ada sistem rotasi. Oleh karena itu, pembelajaran tipe ini sangat membantu siswa untuk memperoleh hasil belajar yang maksimal. Dengan demikian penggunaan strategi RTE dalam proses pembelajaran memungkinkan siswa berinteraksi bukan hanya dengan kelompoknya melainkan dengan kelompok-kelompok lain dalam suatu pembelajaran. Sehingga diharapkan kegiatan belajar akan dirasakan lebih menyenangkan untuk siswa serta menambah motifasi siswa dalam belajar (Hasanah et al., 2019; ).

Hasil penelitian (Hasanah et al., 2019) mendapatkan bahwa pembelajaran menggunakan model pembelajaran kooperatif tipe Rotating Trio Exchange (RTE) berpengaruh secara signifikan terhadap hasil belajar siswa kelas $\mathrm{V}$ SD Negeri Pinggir Papas 1 Sumenep. Selain itu RTE juga dapat menumbuhkan minat belajar siswa, pembelajaran dapat dilakukan dengan baik sesuai dengan tahapan RPP, serta siswa 
aktif dengan saling membantu dalam menguasai materi pelajaran. Hasil kajian Yahya (2020) memaparkan bahwa penerapan model pembelajaran kooperatif tipe rotating trio exchange terbukti dapat meningkatkan keaktifan siswa dari katagori sedang pada siklus I hingga meningkat dengan katagori sangat tinggi pada siklus III. Hal ini menunjukkan bahwa model RTE dapat diterapkan untuk meningkatkan keterampilan sosial siswa.

Tujuan dari penelitian ini adalah untuk mendeskripsikan hasil observasi keterampilan sosial dan perubahan keterampilan sosial siswa di kelas yang menggunakan model pembelajaran kooperatif tipe RTE dibandingkan dengan siswa di kelas yang menggunakan model pembelajaran konvensional pada materi momentum dan impuls di kelas $X$ MIPA SMA Negeri 5 Pekanbaru.

\section{Bahan dan Metode}

Penelitian penerapan model pembelajaran kooperatif tipe rotating trio exchange (RTE) pada materi momentum dan impuls dilaksanakan di kelas X MIPA SMA Negeri 5 Pekanbaru. Waktu penelitian dilaksanakan pada tahun ajaran 2018/2019.

Jenis penelitian menggunakan preeksperimen dengan rancangan intact-group comparison (Sugiyono, 2016). Penelitian ini dilakukan pada dua kelas yang diberikan perbedaan perlakuan yaitu: kelas eksperimen dan kelas kontrol. Kelas eksperimen menggunakan model pembelajaran kooperatif tipe RTE, sedangkan kelas kontrol mengikuti pembelajaran konvensional. Rancangan penelitian ini dilakukan menurut Gambar 1.

\begin{tabular}{|lll|}
\hline Kelas Eksperimen & $\mathrm{X}$ & $\mathrm{O}_{1}$ \\
Kelas Kontrol & & $\mathrm{O}_{2}$ \\
\hline
\end{tabular}

Gambar 1. Rancangan intact-group comparison.

Keterangan :
$\mathrm{X}=$ Perlakuan dengan menggunakan model pembelajaran kooperatif tipe RTE

$\mathrm{O}_{1}=$ Hasil posttest kelas eksperimen

$\mathrm{O}_{2}=$ Hasil posttest kelas kontrol

Subjek penelitian adalah siswa X MIPA 2 yang berjumlah 36 siswa terdiri dari 16 siswa laki-laki dan 20 siswa perempuan sebagai kelompok kontrol dan siswa X MIPA 4 yang juga berjumlah 36 siswa terdiri dari 16 siswa laki-laki dan 20 siswa perempuan sebagai kelompok eksperimen. Teknik pengumpulan data diperoleh dari hasil observasi keterampilan sosial siswa terkait indikator: mendengar dengan aktif, mengambil giliran dalam berbagi tugas, mengajukan pertanyaan, kerjasama dan toleransi. Tahap awal kajian dilakukan dengan mengumpulkan data keterampilan sosial siswa dari masing-masing wali kelas X MIPA SMA Negeri 5 Pekanbaru. Selanjutnya menentukan kelas kontrol yang akan menggunakan metode pembelajaran konvensional dan kelas eksperimen yang akan diberi perlakuan penerapan model pembelajaran kooperatif tipe RTE. Setelah diberikan treatment (perlakuan), observer mengamati keterampilan sosial siswa selama proses pembelajaran berlangsung untuk tiga kali pertemuan baik pada kelas eksperimen maupun kelas kontrol dan memberikan skor penilaian keterampilan sosial siswa terhadap hasil observasi.

Adapun teknik analisis data yang digunakan pada penelitian ini adalah teknik analisis deskriptif untuk menggambarkan hasil observasi keterampilan sosial siswa setelah dilaksanakan pembelajaran melalui penerapan model pembelajaran kooperatif tipe RTE. Untuk menentukan besarnya peningkatan keterampilan sosial siswa, ditentukan berdasarkan nilai persentase hasil observasi keterampilan sosial siswa.

\section{Hasil dan Pembahasan}

Data yang diperoleh pada penelitian ini berupa data hasil observasi keterampilan sosial siswa kelas X MIPA 4 dan X MIPA 2 SMAN 5 Pekanbaru yang merupakan hasil observasi langsung dapat dilihat pada Tabel 1. 
Berdasarkan Tabel 1 secara umum diperoleh informasi bahwa terdapat perbedaan persentase rata-rata dan tingkat kategori keterampilan sosial siswa antara kelas kontrol dan kelas eksperimen pada setiap pertemuan. Keterampilan sosial siswa baik pada kelas kontrol maupun kelas eksperimen mengalami peningkatan untuk setiap pertemuan. Namun peningkatan keterampilan sosial pada kelas eksperimen lebih signifikan dibanding kelas kontrol. Tinjauan pada kelas kontrol, menunjukkan indikator keterampilan sosial siswa yang memiliki persentase rata-rata terendah adalah indikator 3 yaitu dengan nilai $49,33 \%$, dan indikator dengan skor tertinggi adalah indikator 2 dengan nilai persentase rata-rata $75,67 \%$. Tidak jauh berbeda dengan kelas kontrol, indikator keterampilan sosial siswa yang memiliki skor terendah pada kelas eksperimen juga berada pada indikator 3 yaitu dengan nilai $66,67 \%$, dan skor tertinggi berada pada indikator 2 dengan persentase rata-rata $86,33 \%$.

Tabel 1. Hasil pengamatan keterampilan sosial siswa

\begin{tabular}{|c|c|c|c|c|c|c|c|c|c|c|c|c|c|c|c|c|c|}
\hline \multirow{3}{*}{ No } & \multirow{3}{*}{$\begin{array}{c}\text { Indikator } \\
\text { Keteram- } \\
\text { pilan Sosial }\end{array}$} & \multicolumn{4}{|c|}{ Pertemuan I } & \multicolumn{4}{|c|}{ Pertemuan II } & \multicolumn{4}{|c|}{ Pertemuan III } & \multicolumn{4}{|c|}{ Rata-rata } \\
\hline & & \multicolumn{2}{|c|}{$(\%)$} & \multicolumn{2}{|c|}{ Kategori } & \multicolumn{2}{|c|}{$(\%)$} & \multicolumn{2}{|c|}{ Kategori } & \multicolumn{2}{|c|}{$(\%)$} & \multicolumn{2}{|c|}{ Kategori } & \multicolumn{2}{|c|}{$(\%)$} & \multicolumn{2}{|c|}{ Kategori } \\
\hline & & $\mathbf{K}$ & $\mathbf{E}$ & $\mathbf{K}$ & $\mathbf{E}$ & $\mathbf{K}$ & $\mathbf{E}$ & $\mathbf{K}$ & $\mathbf{E}$ & $\mathbf{K}$ & $\mathbf{E}$ & $\mathbf{K}$ & $\mathbf{E}$ & $\mathbf{K}$ & $\mathbf{E}$ & $\mathbf{K}$ & $\mathbf{E}$ \\
\hline 1. & $\begin{array}{l}\text { Mendengar } \\
\text { dengan aktif }\end{array}$ & 69 & 78 & S & $\mathrm{T}$ & 74 & 87 & S & $\mathrm{T}$ & 78 & 91 & $\mathrm{~T}$ & $\mathrm{~T}$ & 73,67 & 85,33 & S & $\mathrm{T}$ \\
\hline 2. & $\begin{array}{l}\text { Mengambil } \\
\text { giliran dalam } \\
\text { berbagi } \\
\text { tugas }\end{array}$ & 73 & 82 & $\mathrm{~S}$ & $\mathrm{~T}$ & 75 & 88 & S & $\mathrm{T}$ & 79 & 89 & $\mathrm{~T}$ & $\mathrm{~T}$ & 75,67 & 86,33 & $\mathrm{~T}$ & $\mathrm{~T}$ \\
\hline 3. & $\begin{array}{l}\text { Mengajukan } \\
\text { pertanyaan }\end{array}$ & 44 & 54 & $\mathrm{R}$ & S & 48 & 70 & $\mathrm{R}$ & S & 56 & 76 & S & $\mathrm{T}$ & 49,33 & 66,67 & $\mathrm{R}$ & S \\
\hline 4. & $\begin{array}{l}\text { Kerjasama } \\
\text { (gotong } \\
\text { royong) }\end{array}$ & 66 & 80 & S & $\mathrm{T}$ & 67 & 85 & S & $\mathrm{T}$ & 69 & 89 & S & $\mathrm{T}$ & 67,33 & 84,67 & S & $\mathrm{T}$ \\
\hline 5. & Toleransi & 70 & 76 & S & $\mathrm{T}$ & 72 & 83 & $\mathrm{~S}$ & $\mathrm{~T}$ & 74 & 87 & S & $\mathrm{T}$ & 72,00 & 82,00 & S & $\mathrm{T}$ \\
\hline
\end{tabular}

Keterangan : $\mathrm{K}=$ Kelas kontrol, $\mathrm{E}=$ Kelas eksperimen, $\mathrm{R}=$ Rendah, $\mathrm{S}=$ Sedang, $\mathrm{T}=$ Tinggi.

Tabel 2. Rata-rata dan standar deviasi keterampilan sosial siswa

\begin{tabular}{|c|c|c|c|c|c|c|c|c|c|c|c|c|c|}
\hline \multirow{3}{*}{ No. } & \multirow{3}{*}{$\begin{array}{c}\text { Indikator } \\
\text { Keterampilan } \\
\text { Sosial }\end{array}$} & \multicolumn{4}{|c|}{ Pertemuan I } & \multicolumn{4}{|c|}{ Pertemuan II } & \multicolumn{4}{|c|}{ Pertemuan III } \\
\hline & & \multicolumn{2}{|c|}{$\bar{x}$} & \multicolumn{2}{|c|}{ SD } & \multicolumn{2}{|c|}{$\bar{x}$} & \multicolumn{2}{|c|}{ SD } & \multicolumn{2}{|c|}{$\bar{x}$} & \multicolumn{2}{|c|}{ SD } \\
\hline & & Ktrl & Eks & Ktrl & Eks & Ktrl & Eks & Ktrl & Eks & Ktrl & Eks & Ktrl & Eks \\
\hline 1. & $\begin{array}{l}\text { Mendengarkan } \\
\text { dengan aktif }\end{array}$ & 2,75 & 3,16 & 0,75 & 0,58 & 2,97 & 3,47 & 0,64 & 0,49 & 3,14 & 3,63 & 0,67 & 0,48 \\
\hline 2. & $\begin{array}{l}\text { Mengambil } \\
\text { giliran dalam } \\
\text { berbagi tugas }\end{array}$ & 2,91 & 3,27 & 0,68 & 0,56 & 3,00 & 3,52 & 0,52 & 0,49 & 3,16 & 3,55 & 0,55 & 0,49 \\
\hline 3. & $\begin{array}{l}\text { Mengajukan } \\
\text { pertanyaan }\end{array}$ & 1,78 & 2,08 & 1,03 & 1,21 & 1,91 & 2,80 & 1,08 & 1,04 & 2,22 & 3,05 & 0,68 & 1.02 \\
\hline 4. & $\begin{array}{l}\text { Kerjasama } \\
\text { (gotong royong) }\end{array}$ & 2,63 & 3,19 & 0,67 & 0,39 & 2,70 & 3,41 & 0,56 & 0,49 & 2,75 & 3,55 & 1,03 & 0,49 \\
\hline 5. & Toleransi & 2,78 & 3,05 & 0,67 & 0,47 & 2,86 & 3,30 & 0,63 & 0,46 & 2,97 & 3,50 & 0,67 & 0,50 \\
\hline
\end{tabular}

Keterangan $: \bar{x}=$ rata-rata indikator, $\mathrm{SD}=$ standar deviasi. 
Untuk mengetahui keberhasilan penerapan model kooperatif tipe RTE terhadap keterampilan sosial siswa pada penelitian ini dikategorikan berdasarkan nilai rata-rata dan standar deviasi yang terukur. Nilai rata-rata dan standar deviasi tersebut dianalisis untuk setiap indikator keterampilan sosial siswa. Nilai ratarata dan standar deviasi keterampilan sosial siswa untuk semua indikator pada setiap pertemua dapat dilihat pada Tabel 2.

Berdasarkan Tabel 2 didapatkan bahwa rata-rata indikator dan standar deviasi keterampilan sosial siswa pada kelas kontrol dan kelas eksperimen menunjukkan hasil yang berbeda. Standar deviasi keterampilan sosial siswa kelas kontrol yang menerapkan model pembelajaran konvensional untuk semua indikator belum menunjukkan variabilitas data yang semakin kecil atau data yang didapatkan belum menuju sifat homogenitas. Standar deviasi yang diperoleh kelas eksperimen yang menerapkan model pembelajaran kooperatif tipe RTE untuk indikator 1, 2, dan 3 sudah menuju variabilitas data yang semakin kecil atau datanya semakin menuju sifat homogenitas, sedangkan untuk indikator 4 dan indikator 5 masih mendapatkan angka yang belum teratur, meskipun untuk indikator 5 pada pertemuan I dan II sudah menuju angka semakin kecil, namun kembali meningkat pada pertemuan III. Semakin besar standar deviasi yang diperoleh suatu data, maka semakin besar variabilitas datanya atau semakin kurang homogen. Sebaliknya, apabila standar deviasi kecil, maka data yang diperoleh semakin dekat kepada sifat homogenitas (Anas, 2014). Adapun kategori keterampilan sosial siswa baik pada kelas kontrol maupun kelas eksperimen ditunjukkan pada Tabel 3.

Berdasarkan Tabel 3 dapat diketahui bahwa kategori keterampilan sosial siswa baik pada kelas kontrol maupun kelas eksperimen keduanya mengalami perubahan yang berbedabeda. Untuk kelas kontrol masih ditemui keterampilan sosial siswa yang berada dalam kategori rendah disetiap pertemuannya. Melalui hasil pengamatan keketerampilan sosial siswa kelas eksperimen yang menerap-kan model pembelajaran kooperatif tipe RTE dapat dilihat bahwa persentase kategori keterampilan sosial siswa mengalami perubahan yang signifikan. Pertemuan I, II dan III tidak ditemui keterampilan sosial siswa yang berada dalam kategori rendah. Hasil analisis deskriptif diperoleh persentase keterampilan sosial siswa bedasarkan Tabel 1 pada masing-masing indikator untuk tiga kali pertemuan dalam pembelajaran fisika pada materi momentum dan impuls mengalami peningkatan yang lebih baik.

Tabel 3. Kategori hasil pengamatan keterampilan sosial siswa

\begin{tabular}{llcccccc}
\hline \multirow{2}{*}{ No. } & \multirow{2}{*}{ Kategori } & \multicolumn{2}{c}{$\begin{array}{c}\text { Pertemuan I } \\
(\%)\end{array}$} & \multicolumn{2}{c}{$\begin{array}{c}\text { Petemuan II } \\
(\%)\end{array}$} & \multicolumn{2}{c}{$\begin{array}{c}\text { Pertemuan III } \\
(\%)\end{array}$} \\
\cline { 3 - 8 } & & Ktrl & Eks & Ktrl & Eks & Ktrl & Eks \\
\hline 1. & Tinggi & 22,22 & 36,11 & 30,55 & 80,55 & 38,90 & 91,67 \\
2. & Sedang & 52,78 & 63,89 & 55,55 & 19,45 & 55,55 & 8,33 \\
3. & Rendah & 25,00 & - & 13,90 & - & 5,55 & - \\
\hline
\end{tabular}


1. Indikator mendengarkan dengan aktif

Maksud dari indikator mendengarkan dengan aktif dalam penelitian ini adalah siswa yang dapat mendengarkan dan mengarahkan perhatian terhadap penjelasan guru maupun teman yang lainnya, sehingga siswa dapat menyerap informasi secara baik dan jelas. Indikator mendengarkan dengan aktif memberikan penjelasan sederhana yang terdiri atas tiga aspek yaitu: (1) menunjukkan perhatian, (2) mencatat hal yang penting, (3) pandangan ke arah pembicara. Setelah pembelajaran didapati semua indikator pada setiap pertemuan mengalami peningkatan. Adapun rincian yang menunjukkan persentase keterampilan sosial siswa pada indikator mendengarkan dengan aktif dapat dilihat pada Tabel 1.

Berdasarkan data pada Tabel 1 terlihat bahwa frekuensi indikator mendengarkan dengan aktif, untuk pertemuan II meningkat sebesar 9\% dari pertemuan I. Sedangkan pada pertemuan II ke pertemuan III mengalami peningkatan sebesar 4\%. Hal ini terlihat pada saat proses pembelajaran berlangsung yaitu siswa menunjukkan perhatian saat guru menjelaskan dengan menanggapi penjelasan atau informasi yang disampaikan guru, mencatat yang penting dari penjelasan guru tanpa diperintah oleh guru. Hasil ini sesuai dengan kajian Yahya (2020) yang dapat meningkatkan keaktifan siswa dalam proses pembelajaran.

2. Indikator mengambil giliran dalam berbagi tugas

Indikator mengambil giliran dalam berbagi tugas yang diamati dalam penelitian ini maksudnya adalah setiap siswa bersedia menerima tugas dalam kelompok, siswa bersedia melaksanakan tugas yang diberikan dengan penuh tanggung jawab, dan siswa saling membantu dalam menyelesaikan tugas kelompok tepat pada waktunya. Setiap siswa memberikan kontribusi dalam mengerjakan tugas dalam kelompok, sehingga tugas yang diberikan berjalan dengan efektif dan memperoleh hasil yang baik. Indikator mengambil giliran dalam berbagi tugas adalah indikator yang memiliki persentase tertinggi yaitu $86,33 \%$ dibandingkan indikator lain untuk tiga kali pertemuan. Hal ini hal ini disebabkan pada penerapan strategi pembelajaran RTE yang beranggotakan tiga orang, terdapat tahapan mengerjakan soal dalam waktu singkat yang mampu mendorong siswa untuk aktif berbagi tugas agar dapat menyelesaikannya demi kepentingan kelompok. Adapun rincian yang menunjukkan persentase keterampilan sosial siswa pada indikator mengambil giliran dalam berbagi tugas dapat dilihat pada Tabel 1 .

Berdasarkan data pada Tabel 1 dapat dilihat rentang frekuensi mengalami perubahan sebesar $6 \%$ pada pertemuan II dari pertemuan I dan $1 \%$ pada pertemuan III dari pertemuan II. Terjadinya perubahan ini dikarenakan pada pertemuan II merupakan kegiatan pem-belajaran lanjutan dari pertemuan I dengan materi yang berbeda, namun dengan teknik pembelajaran yang sama, sedangkan pada pertemuan III pembelajaran kooperatif diterapkan melalui eksperimen dan demonstrasi yang membuat siswa lebih bersemangat pada saat mengambil giliran dalam berbagi tugas. Hal ini membuat siswa lebih bersedia menerima tugas saat melakukan percobaan, melaksanakan percobaan sederhana materi tumbukan lenting sebagian, dan bisa menyelesaikan tugas yang diberikan oleh guru kepada kelompok tepat pada waktunya. Hasil penelitian ini relevan dengan penelitian yang dilakukan oleh Srihidayah (2008) yaitu mengalami peningkatan untuk indikator mengambil giliran dalam berbagi tugas disetiap pertemuan, meskipun angka peningkatan persentase yang diperoleh Srihidayah cukup besar dibandingkan dengan penelitian ini.

\section{Indikator mengajukan pertanyaan}

Indikator mengajukan pertanyaan yang dimaksud dalam penelitian ini adalah siswa meminta suatu penjelasan atau informasi lebih lanjut tentang materi yang diajarkan dan tugas yang diberikan oleh guru dengan pertanyaan sesuai dengan materi pelajaran, pertanyaan yang singkat dan jelas, dan siswa bertanya dengan intonasi yang baik. Melalui penelitian ini, indikator mengajukan pertanyaan merupakan indikator yang memperoleh rentang persentase paling rendah dibanding dengan indikator lain yang terukur meskipun tetap mengalami peningkatan pada setiap pertemuan. Hasil yang menunjukkan keterampilan sosial siswa pada 
indikator mengajukan pertanyaan dapat dilihat pada Tabel 1.

Berdasarkan data pada Tabel 1 dapat diketahui bahwa frekuensi keterampilan sosial siswa pada indikator mengajukan pertanyaan mengalami peningkatan pada setiap pertemuan. Untuk pertemuan II meningkat sebesar $16 \%$ dari pertemuan I, sedangkan pada pertemuan III meningkat sebesar $6 \%$ dari pertemuan II. Hasil penelitian ini relevan dengan penelitian yang dilakukan oleh Srihidayah (2008) yaitu mengalami peningkatan untuk indikator mengajukan pertanyaan pada setiap pertemuan, hanya saja hasilnya kategori sedang, meskipun angka peningkatan persentase yang diperoleh cukup kecil dibandingkan dengan indikator keterampilan sosial lainnya, namun selisihnya tidak terlalu jauh. Hal ini menujukkan siswa masih perlu terus dilatih untuk membiasakan diri terampil dalam mengajukan pertanyaan tekait materi yang dipelajari.

\section{Indikator kerjasama (gotong royong)}

Kerjasama (gotong royong) yang dimaksud disini yaitu siswa aktif dalam mengikuti pembelajaran secara bersama (kooperatif), siswa yang memiliki kemampuan lebih dalam pembelajaran diharapkan ikut aktif dalam membantu temannya yang mengalami kesulitan serta mendorong keaktifan dalam bekerjasama pada semua anggota kelompok. Setiap siswa aktif dalam diskusi kelompok memberikan kontribusi dalam mengerjakan tugas dalam kelompok, sehingga tugas yang diberikan berjalan dengan efektif dan memperoleh hasil yang baik dengan saling membantu antar anggota kelompok. Hasil kajian keterampilan sosial siswa pada indikator kerjasama (gotong royong) sesuai Tabel 1.

Berdasarkan data pada Tabel 1 dapat dilihat rentang frekuensi indikator kerjasama (gotong royong) pada pertemuan I ke pertemuan II mengalami perubahan sebesar 5\% dan pada pertemuan II ke pertemuan III mengalami peningkatan sebesar 4\%. Hasil selisih persentase, bisa dilihat bahwa antara pertemuan II dari pertemuan I dan antara pertemuan III dari pertemuan II mengalami peningkatan yang tidak berbeda. Hal ini dikarenakan untuk pertemuan berikutnya siswa mulai terlatih untuk bertanggungjawab dalam melaksanakan tugas yang diberikan dan menyelesaikan tugas tepat waktu. Pada pertemuan III persentase keterampilan sosial siswa mencapai persentase rata-rata tertinggi yaitu $89 \%$ dikarenakan siswa cukup aktif dalam kerja kelompok dengan mempraktikkan tumbukan lenting sebagian bersama teman kelompoknya. Praktikum ini membuat siswa lebih antusias untuk aktif dalam kelompok, saling kerjasama dalam membantu teman sekelompok yang masih kurang dalam memahami pembelajaran, dan mendorong teman sekelompok untuk bisa mempraktikkan percobaan dengan bergantian mengerjakan kegiatan pada saat percobaan dalam memperoleh data pertama. Data hasil penenlitian ternyata semakin meningkat sesuai dengan penelitian yang telah dilakukan oleh Lestari \& Linuwih (2012), dalam mengamati keterampilan sosial siswa untuk pertemuan I didapatkan $60,4 \%$ dan pertemuan II didapatkan $78,91 \%$, dimana mengalami peningkatan dengan kategori tinggi.

\section{Indikator toleransi}

Toleransi adalah indikator keterampilan sosial siswa yang saling toleran antara yang satu dengan yang lain dalam pembelajaran dengan tidak mengganggu teman yang berbeda pendapat. Siswa saling menerima kesepakatan yang diajukan temannya meskipun berbeda dengan pendapatnya, dan siswa juga tidak memaksakan pendapatnya kepada temannya. Berdasarkan Tabel 2 dapat dilihat bahwa frekuensi indikator kerjasama terus mengalami peningkatan dalam pembelajaran. Data pada Tabel 1 diperoleh hasil pada pertemuan I yaitu sebesar $76 \%$, pada pertemuan II sebesar $83 \%$, dan pada pertemuan III sebesar $87 \%$, dengan rata-rata yang diperoleh yaitu sebesar $82,00 \%$ dengan kategori tinggi.

Melalui pertemuan II dan III siswa semakin terlatih untuk saling menghargai pendapat temannya dalam diskusi kelompok. Kegiatan demonstrasi tentang jenis-jenis tumbukan dan soal yang diberikan guru menghasilkan diskusi yang baik antar kelompok trio. Setiap trio memiliki jawaban dan cara penyelesaian soal yang berbeda-beda. Namun pada saat diskusi berlangsung, setiap kelompok trio terlihat saling mendengarkan penjelasan jawaban dari 
kelompok trio lain. Selain itu, siswa pada tiap kelompok terlihat semakin sabar menunggu giliran untuk menjelaskan hasil diskusi kelompoknya. Beberapa siswa yang kurang sependapat dengan pendapat kelompok trio lain juga sudah menyampaikan tanggapannya dengan santun dan pada waktu yang baik, yaitu ketika sudah dipersilahkan oleh guru untuk menanggapi jawaban dari kelompok lain. Hasil penelitian ini relevan dengan penelitian yang telah dilakukan oleh Yanti et al. (2016) yang menyatakan bahwa untuk indikator ini siswa mulai terbiasa dalam untuk saling menghargai pendapat temannya dalam diskusi kelompok.

\section{Kesimpulan}

Berdasarkan hasil analisis data dan pembahasan yang telah dilakukan terhadap keterampilan sosial siswa kelas X MIPA SMAN 5 Pekanbaru tahun pelajaran 2018/2019, untuk tiga kali pertemuan pada kelas eksperimen dan kelas kontrol, secara deskriptif didapatkan keterampilan sosial siswa kelas eksperimen yang menggunakan model pembelajara kooperatif tipe rotating trio exchange (RTE) lebih tinggi daripada kelas kontrol dengan model pembelajaran konvensional. Keterampilan sosial siswa pada indikator mendengarkan dengan aktif, mengambil giliran dalam berbagi tugas, kerjasama (gotong royong), dan toleransi berkategori tinggi dan hanya indikator mengajukan pertanyaan berkategori rendah. Hal ini ditunjukkan dari persentase rata-rata tiap indikator keterampilan sosial siswa kelas eksperimen lebih tinggi daripada persentase ratarata indikator keterampilan sosial siswa pada kelas kontrol. Persentase rata-rata tiap indikator kelas eksperimen mengalami peningkatan yang cukup signifikan ber-dasarkan standar deviasi keterampilan sosial siswa pada tiap pertemuan yang mengalami peningkatan menuju nilai variabilitas data.

\section{Daftar Pustaka}

Anas, S. (2014). Pengantar Statistik Pendidikan. Jakarta: RajaGrafindo Persada.
Dinan, A. F. (2014). Penerapan Metode Cooperatif Learning Type STAD untuk Meningkatkan Keterampilan Sosial Siswa dalam Pembelajaran Sejarah, Universitas Pendidikan Indonesia. Repositori.upi.edu. Online. Tersedia pada http://jurnal.upi.edu/invotec/view/2928/

Fatimah, S., Jamal, M. A., \& Suyidno. (2013). Meningkatkan Keterampilan Sosial Siswa Melalui Penerapan Pembelajaran Kooperatif Tipe Teams Games Tournament. Berkala Ilmiah Pendidikan Fisika, 1(3), 224-234.

Hasanah, N. F., Nurtaman, M. E., \& Hanik, U. (2019). Pengaruh Model Pembelajaran Kooperatif Tipe Rotating Trio Exchange (Rte) Terhadap Hasil Belajar dan Minat Belajar Matematika Siswa Kelas V SDN Pinggir Papas 1 Sumenep. Widyagogik: Jurnal Pendidikan Dan Pembelajaran Sekolah Dasar, 6(2), 112. https://doi.org/10.21107/widyagogik.v6i2.5 195

Huang, M. Y., Tu, H. Y., Wang, W. Y., Chen, J. F., Yu, Y. T., \& Chou, C. C. (2017). Effects of Cooperative Learning and Concept Mapping Intervention on Critical Thinking and basketball Skills in Elementary School. Thinking Skills and Creativity, 23, 207-216. https://doi.org/10.1016/j.tsc.2017.01.002

Isjoni. (2014). Cooperative Learning Efektifitas Pembelajaran Kelompok. Bandung: Alfabeta.

Lestari, R., \& Linuwih, S. (2012). Penerapan Model Pembelajaran Kooperatif Tipe Pair Checks Pemecahan Masalah untuk Meningkatkan Sosial Skill Siswa. Jurnal Pendidikan Fisika Indonesia. 8(2), 16931246.

Nuraeni, D., Utaya, S., \& Akbar, S. (2016). Pentingnya Pembelajaran Kooperatif dalam Aktivitas Belajar pada Siswa. 1-5.

Sagala, S. (2007). Konsep dan Makna Pembelajaran. Bandung: Alfabeta.

Silberman, M. (2013). Pembelajaran Aktif 101 Strategi untuk Mengajar Secara Aktif. Jakarta: Permata Puri Media.

Srihidayah, W. (2008). Keterampilan Sosial Siswa dalam Pembelajaran Fisika Melalui Pendekatan Kontekstual pada Siswa Kelas 
XI SMA Negeri 1 Pangkalan Lesung. Skripsi Sarjana Pendidikan Fisika FKIP Universitas Riau. Pekanbaru: FKIP UNRI.

Sugiyono. (2016). Metode Penelitian Pendidikan. Bandung: Alfabeta.

Susilowati, S. (2012). Meningkatkan Keterampilan Sosial Siswa Kelas XI IPA2 SMA Negeri 3 Banjarbaru Melalui Penerapan Model Pembelajaran Kooperatif Tipe Numbered Heads Together (NHT) Pada Pokok Bahasan Fluida Statis. Skripsi. Tidak Dipublikasikan. Banjarmasin: UNLAM.
Yahya, A. (2020). Pembelajaran Kooperatif Tipe Rotating Trio Exchange Untuk Meningkatkan Aktivitas dan Hasil Belajar Matematika Siswa. Jurnal Analisa 6(1), 78. http://journal.uinsgd.ac.id/index.php/analisa /index.

Yanti, L., Rahmad, M., \& Zulhelmi. (2016). Kemampuan Keterampilan Sosial Siswa dalam Pembelajaran Fisika Melalui Penerapan Cooperative Learning Teknik SOLO di Kelas XI IPS 3 SMAN 12 Pekanbaru. Jurnal Online Mahasiswa FKIP Universitas Riau. 3(1), 2355-6897. 